\title{
Dietary net energy mainly affects growth performance and pork quality of finishing pigs
}

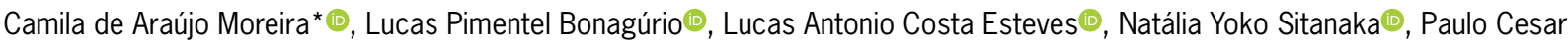 \\ Pozza@
}

\author{
Universidade Estadual de Maringá/CCA - Depto. de \\ Zootecnia, Av. Colombo, 5790 - 87020-900 - Maringá, \\ PR - Brasil. \\ ${ }^{*}$ Corresponding author <caaraujo2@hotmail.com>
}

Edited by: Gerson Barreto Mourão

Received September 25, 2019

Accepted July 23, 2020

\begin{abstract}
The present study was carried out to evaluate the effect of net energy levels in diets for barrows, from 70 to $100 \mathrm{~kg}$, on performance, plasma parameters and carcass characteristics. Two experiments were carried out: in the first (Experiment I), a metabolism assay was carried out to estimate the net energy (NE) of experimental diets. Twelve crossbred barrows, averaging $85.74 \pm 6.80 \mathrm{~kg}$ initial body weight, were distributed in a randomized block design with two metabolizable energy (ME) levels (3100 and $3500 \mathrm{kcal} \mathrm{kg}^{-1}$ ) with six replicates and one animal per experimental unit. In the second (Experiment II), 45 castrated male pigs were used, averaging $70.10 \pm 1.26 \mathrm{~kg}$ of initial body weight distributed in a randomized block design, with five NE levels $\left(2345,2425,2505,2585,2665 \mathrm{kcal} \mathrm{kg}^{-1}\right)$, nine replicates and one animal per experimental unit. The increase in diet NE levels provided a linear reduction ( $p \leq 0.00039$ ) in average daily feed intake (ADFI). There was a quadratic effect on NE efficiency ( $p \leq 0.0027)$, average daily gain (ADG), ( $p \leq 0.0352)$ and the feed:gain ratio $(F: G),(p \leq 0.0024)$, the optimal levels being estimated at 2485, 2493 and $2533 \mathrm{kcal} \mathrm{kg}^{-1}$, respectively. Drip loss (DL) decreased $(p \leq 0.0001)$ as NE levels increased. There was also a linear decrease $(p \leq 0.0462)$ in the Minolta color parameter $\left(+a^{*}\right)$, due to the NE levels. Plasma parameters were not affected $(p>0.05)$ by $\mathrm{NE}$ levels. The dietary net energy levels affected the performance and meat quality of finishing pigs and the level of $2493 \mathrm{kcal} \mathrm{kg}^{-1}$ provided the best ADG.
\end{abstract}

Keywords: body weight gain, prediction equation, energy requirement for production, qualitative parameters of meat pigs

\section{Introduction}

On swine farms in Brazil, the diets are usually formulated based on metabolizable energy (ME). However, the use of digestible energy (DE) and ME in diet formulation may overestimate protein and fiber digestibility (Weber et al., 2010), or underestimate starch and fat digestibility (Noblet et al., 1994; Noblet, 2007). In this context, the use of NE can be observed in several countries, still considered as the most accurate energy system for swine production. Thus, a consistent database should be made available to provide adequate results, allowing for widespread use of the NE system as the basis for formulating diets (Velayudhan and Nyachoti, 2016).

The differences between the ME and NE systems are in the energy expenditure associated with diet heat increment (HI), which can be defined as the heat generated by metabolic processes during nutrient absorption and metabolization. This energy can be dissipated into the environment or used to maintain body temperature on cold days (Kil et al, 2013; Moehn et al., 2013).

Optimal NE levels are determined by calculating the energy that will actually be consumed by swine during maintenance and production processes. In connection with this, Rostagno et al. (2005) used a prediction equation to estimate NE values of feedstuffs. This equation was initially proposed by Noblet et al. (1994) and was fitted using total diet information. Subsequently, Rostagno et al. (2017) established the NE value estimations by means of the aforementioned equation, consolidating it as the model for feed NE value estimation under conditions prevalent in Brazil.

Adequate knowledge of the energy value in the ingredients makes it possible to include several feedstuffs in swine and poultry diets with greater accuracy, thereby improving feed efficiency and reducing diet formulation costs (Noblet et al., 1994; Kil et al., 2013). In addition, swine performance improves significantly when the NE system is deployed (Li et al., 2018). However, factors such as weight gain, physiological stage, chemical composition of feedstuffs and energy level may affect pig performance (Schinckel et al., 2012), making it necessary to determine the best NE levels for the different production stages.

Thus, the objective of the present study was to evaluate the optimal dietary NE in terms of performance, blood parameters, carcass traits and pork quality of finishing pigs.

\section{Materials and Methods}

The experimental station was located at Maringá $\left(23^{\circ} 21^{\prime} 21.6^{\prime \prime} \mathrm{S}, 52^{\circ} 04^{\prime} 18.9^{\prime \prime} \mathrm{W}\right.$, altitude of $\left.564 \mathrm{~m}\right)$, in the state of Paraná, Brazil. The experimental procedures were approved by the Ethics Committee on the Use of Animals of the State University of Maringá (Protocol 5920100217).

\section{Experiment I: Net energy determination of experimental diets}

Twelve barrows averaging $85.74 \pm 6.80 \mathrm{~kg}$ were individually allotted to metabolism cages similar to those 
described by Pekas (1968), in a completely randomized block design consisting of two treatments and six replicates. The temperature was partially controlled (with the aid of air conditioning) throughout the experimental period, with minimum and maximum temperatures of $22.8 \pm 1.62{ }^{\circ} \mathrm{C}$ and $27.6 \pm 1.33^{\circ} \mathrm{C}$, respectively.

Treatments consisted of one diet with $3100 \mathrm{kcal}$

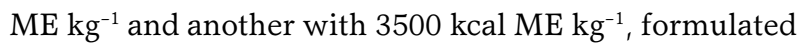
with corn, soybean meal, vitamins, minerals and additives (Table 1), in order to meet the requirements proposed by Rostagno et al. (2017). Feces and urine were collected following the methodologies described by Sakomura and Rostagno (2016).

Feed intake was established based on metabolic weight $\left(\mathrm{P}^{0.75}\right)$ and feeding was divided into $59 \%$ in the morning and $41 \%$ in the afternoon (a proportion obtained based on the intakes between morning and afternoon during the adaptation period). The diets were moistened with water, in approximately $20 \%$ of the feed provided, to avoid waste, reduce the pulverulence and improve its acceptability. After each meal, water was supplied in the feeder itself in the proportion of five $\mathrm{mL}$ of water $\mathrm{g}^{-1}$ of feed, to avoid excess water intake and not compromise feed intake.

Table 1 - Ingredients, chemical and energetic composition of basal diets.

\begin{tabular}{|c|c|c|}
\hline \multirow{2}{*}{ Ingredients \% } & \multicolumn{2}{|c|}{ Metabolizable energy $\left(\mathrm{kcal} \mathrm{kg}^{-1}\right)$} \\
\hline & 3100 & 3500 \\
\hline Corn & 70.40 & 70.40 \\
\hline Soybean meal 45 \% & 21.57 & 21.57 \\
\hline Soybean Oil & 0.66 & 5.48 \\
\hline Inert $^{1}$ & 4.82 & 0.00 \\
\hline Bicalcium Phosphate & 0.87 & 0.87 \\
\hline Limestone & 0.60 & 0.60 \\
\hline Salt & 0.36 & 0.36 \\
\hline Premix ${ }^{2}$ & 0.40 & 0.40 \\
\hline L-lysine $\mathrm{HCl} 78.4$ \% & 0.20 & 0.20 \\
\hline DL-methionine $99 \%$ & 0.04 & 0.04 \\
\hline L-threonine $98.5 \%$ & 0.04 & 0.04 \\
\hline Growth promoter ${ }^{3}$ & 0.02 & 0.02 \\
\hline Antioxidant ${ }^{4}$ & 0.02 & 0.02 \\
\hline \multicolumn{3}{|l|}{ Composition } \\
\hline $\mathrm{BED}\left(\mathrm{mEq} \mathrm{kg}{ }^{-1}\right)$ & 152.72 & 152.72 \\
\hline Metabolizable Energy (kcal kg-1) & 3100 & 3500 \\
\hline Crude protein (\%) & 15.53 & 15.53 \\
\hline Digestible phosphorus (\%) & 0.250 & 0.250 \\
\hline Calcium (\%) & 0.512 & 0.512 \\
\hline Sodium (\%) & 0.160 & 0.160 \\
\hline SID Lysine (\%) & 0.829 & 0.829 \\
\hline SID Methionine + cystine (\%) & 0.497 & 0.497 \\
\hline SID Threonine (\%) & 0.555 & 0.555 \\
\hline \multicolumn{3}{|c|}{$\begin{array}{l}{ }^{1} \text { Clean sand; }{ }^{2} \text { Amount kg-1 of diet; vit. A: } 30000 \mathrm{IU} \text {, vit. D3: } 5000 \mathrm{IU} \text {, vit. E: } 12 \\
\text { IU, vit. K: } 5 \mathrm{mg} \text {, vit. B12: } 120 \mathrm{mcg} \text {, Niacin: } 150 \mathrm{mg} \text {, Calcium Panthothenate } \\
75 \mathrm{mg} \text {, Folic Acid: } 8 \mathrm{mg} \text {, Choline Chloridate: } 0.48 \mathrm{~g} \text {, Iron: } 350 \mathrm{mg} \text {, Copper } \\
15 \mathrm{mg} \text {, Magnesium: } 250 \mathrm{mg} \text {, Zinc: } 0.75 \mathrm{~g} \text {, lodine: } 10 \mathrm{mg} \text {, Selenium: } 3 \mathrm{mg} \\
{ }^{3} \text { Enramycin; }{ }^{\text {BBanox. }}\end{array}$} \\
\hline
\end{tabular}

The experimental period lasted for twelve days, being seven days of adaptation to the metabolism cages and the diets and five days of feces and urine which were collected once a day at $08 \mathrm{~h} 00$. To define the beginning and the end of the collection period ferric oxide $\left(\mathrm{Fe}_{2} \mathrm{O}_{3}\right)$ was used as a fecal marker.

The urine, as it was excreted, was filtered and collected in plastic buckets located at the cage bottom,

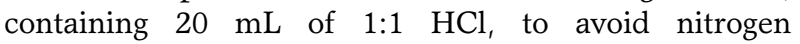
volatilization and bacterial proliferation. At the end of the urine collection, a $10 \%$ aliquot of each animal was stored and frozen $\left(-18^{\circ} \mathrm{C}\right)$ for further analysis. The feces were collected once a day, in plastic bags, identified and stored in a freezer until the end of the collection period. Subsequently, the material was homogenized and dried in a forced ventilation oven $\left(55^{\circ} \mathrm{C}\right)$ for $72 \mathrm{~h}$ and milled in a knife-type mill with a $1 \mathrm{~mm}$ sieve.

The gross energy (GE) of experimental diets, feces and urine were determined in the Research Support Center Complex (COMCAP) by adiabatic calorimeter.

The diets were analyzed for dry matter (DM, method 930.15), crude protein (CP, method 990.03), ether extract (EE, method 920.39) and crude fiber $(\mathrm{CF}$, method 978.10) according to the methodologies described by AOAC (2006). The starch (S) analysis was performed by $\mathrm{ABC}$ laboratories using the enzymatic method. The values of $\mathrm{DE}, \mathrm{ME}$, digestibility (GECD) and metabolizable (GEMC) coefficients of gross energy as well as the ME: DE ratio of experimental diets were determined.

The bromatological composition (EE, S, CP and $\mathrm{CF}$ ) and DM values were used in the prediction equation proposed by Noblet et al. (1994), as follows: $\mathrm{NE}=$ $0.730 \mathrm{ME}+1.31 \mathrm{EE}+0.37 \mathrm{~S}-0.67 \mathrm{CP}-0.97 \mathrm{CF}$.

\section{Experiment II - Performance, blood parameters, carcass traits and pork quality}

The minimum and maximum temperatures recorded during the experimental period were $19.8 \pm 1.33^{\circ} \mathrm{C}$ and $30.6 \pm 1.62{ }^{\circ} \mathrm{C}$, respectively.

A total of 45 crossbreed swine, castrated males, averaging $70.10 \pm 1.26 \mathrm{~kg}$ were used. The animals were housed in a masonry shed, covered with asbestos cement tiles, divided into two sections, each one consisting of twenty stalls $\left(3.80 \mathrm{~m}^{2}\right)$ separated by a central hall. The stalls were equipped with a nipple type drinker and semiautomatic feeders, providing free access to feed and water, dispensed ad libitum throughout the experimental period.

The animals were distributed, based on the initial weight, in a randomized complete block design, consisting of five NE levels $(2345,2425,2505,2585$ and $2665 \mathrm{kcal} \mathrm{kg}^{-1}$ ), nine replicates and one animal per experimental unit.

The experimental diets were formulated with corn, soybean meal, vitamins, minerals and additives (Table 1) to meet the requirements proposed by Rostagno et al. (2011), for castrated male swine of high genetic potential and superior performance in the finishing phase $(70-100 \mathrm{~kg})$. 
The highest and lowest NE levels of the experimental diets were previously identified in Experiment I. Subsequently, the dilution technique was carried out to obtain the intermediate NE levels as shown in Table 2.

The animals were weighed at the beginning and end of the experiment to determine the average daily gain (ADG). The diets were weighed when provided to animals to determine the average daily feed intake (ADFI). The ADG and ADFI data were used to calculate the feed:gain ratio (F:G). NE Intake (ADFI g ${ }^{-1} \times \mathrm{kcal} \mathrm{NE}^{-1}$ $\mathrm{kg}^{-1}$ of diet) and NE efficiency (NE Intake (kcal ADG $\mathrm{kg}^{-1}$ ) were also calculated.

At the end of the experiment, the animals were fasted for six $\mathrm{h}$ before blood was taken. Blood samples were drawn from the jugular vein (Cai et al., 1994) and transferred to tubes with EDTA (urea, triglycerides and total cholesterol) or fluoride (glucose analysis) and centrifuged at 3000 revolutions per min (rpm) for fifteen min for plasma separation (Moreno et al., 1997). Then three $\mathrm{mL}$ of plasma were transferred to eppendorf tubes, previously identified and stored in a freezer $\left(-18^{\circ} \mathrm{C}\right)$, for further analysis.

The glucose, urea, triglycerides and total cholesterol analyses were carried out by the colorimetric method, using commercial kits, following the specific standard operating procedures (SOP).

After $24 \mathrm{~h}$ of fasting, the animals were weighed to obtain the slaughter live weight and sent to the slaughter house of the experimental station. The animals were submitted to electrical stunning (200 watts) and then killed by exsanguination, shaved, and gutted. The eviscerated carcasses were divided in the middle, in the longitudinal direction, and later weighed and cooled $(2$ $\pm 1{ }^{\circ} \mathrm{C}$ per $24 \mathrm{~h}$ ).

The carcasses were individually evaluated according to the guidelines of Bridi and Silva (2009), whereby the hot carcass weight (HCW) was determined together with cold carcass weight (CCW), ham weight (HW), hot carcass yield (HCY), cold carcass weight loss (CCWL), ham yield (HY), backfat thickness (BT) and Longissimus dorsi depth (LDD).

Table 2 - Dilution of experimental diets used in the digestibility experiment to obtain the treatments (T) used in performance experiment.

\begin{tabular}{|c|c|c|c|}
\hline \multirow{2}{*}{ Treatments } & Energy Dilution & Determined & Estimated \\
\hline & ME & $\mathrm{ME}^{1}$ & $\mathrm{NE}^{2}$ \\
\hline & \multicolumn{3}{|c|}{$\longrightarrow \mathrm{kcal} \mathrm{kg}^{-1} \longrightarrow$} \\
\hline T1 & $100 \% \mathrm{~T} 1$ & $3120^{3}$ & $2345^{3}$ \\
\hline T2 & $75 \% \mathrm{~T} 1+25 \% \mathrm{~T} 5$ & 3214 & 2425 \\
\hline T3 & $50 \% \mathrm{~T} 1+50 \% \mathrm{~T} 5$ & 3308 & 2505 \\
\hline T4 & $25 \% \mathrm{~T} 1+75 \% \mathrm{~T} 5$ & 3401 & 2585 \\
\hline T5 & $100 \%$ T5 & $3495^{3}$ & $2665^{3}$ \\
\hline
\end{tabular}

BT and LDD were measured in the left half carcass, $24 \mathrm{~h}$ post-mortem, using a pachymeter, in the insertion region of the last thoracic vertebra with the first lumbar, at a point six $\mathrm{cm}$ from the carcass cut midline (point $\mathrm{P} 2$ ).

The $\mathrm{pH}$ of the Longissimus dorsi muscle was measured in the warm carcass, 45 min after slaughter (pH45) and in the cold carcass kept in the cold chamber (1 $-2{ }^{\circ} \mathrm{C}$ ) for $24 \mathrm{~h}(\mathrm{pH} 24)$ using a digital portable $\mathrm{pH}$ meter following the recommendations of Bridi and Silva (2009).

Two samples $(2.5 \mathrm{~cm}$ thickness) of the muscle were used for the qualitative evaluations as described by Bridi and Silva (2009). The first sample was used to evaluate drip loss (DL), according to the technique described by Boccard et al (1981). The second sample was used to evaluate the meat color parameters. The components $\mathrm{L}^{*}$ (brightness), $\mathrm{a}^{*}$ (red-green component) and $b^{*}$ (yellow-blue component) were expressed in the CIELAB color system.

The data were submitted to statistical analysis using the PROC NLIN in SAS (Statistical Analysis System, version 9.2), using variance analysis (ANOVA) at the $5 \%$ level. For the significant results a polynomial regression analysis was carried out in order to find the linear or quadratic effects as a function of the NE levels studied.

\section{Results and Discussion}

\section{Experiment I - Net energy determination of experimental diets}

The values found for starch were $41.77 \%$ and $40.05 \%$ for diets with the lowest and highest ME levels, respectively (Table 3). These results corroborate the values found in the experimental diets used by Noblet et al. (1994), Quiniou and Noblet (2012) and Smith et al. (2016), who evaluated the diet effect of NE on swine performance in the growth and finishing phases.

Table 3 - Analyzed chemical composition and determined energetic values of the experimental diets.

\begin{tabular}{|c|c|c|}
\hline \multirow{2}{*}{ Item } & \multicolumn{2}{|c|}{ Metabolizable Energy $\left(\mathrm{kcal} \mathrm{kg}^{-1}\right)$} \\
\hline & $3100^{1}$ & $3500^{1}$ \\
\hline Starch, \% & 41.77 & 40.05 \\
\hline Crude Protein, \% & 15.49 & 15.58 \\
\hline Crude Fiber, \% & 2.55 & 2.79 \\
\hline Ether Extract, \% & 3.42 & 7.60 \\
\hline \multicolumn{3}{|l|}{ Determined Energetic Values } \\
\hline Gross Energy, kcal kg-1 & 3600 & 4056 \\
\hline GEDC, \% & 90.98 & 90.29 \\
\hline GEMC, \% & 86.66 & 86.17 \\
\hline Digestible Energy, kcal kg-1 & 3276 & 3662 \\
\hline Metabolizable Energy, kcal kg-1 & 3120 & 3495 \\
\hline ME:DE & 0.952 & 0.954 \\
\hline Net Energy, kcal kg-1 & 2345 & 2665 \\
\hline
\end{tabular}


The dietary crude protein values were $15.49 \%$ and $15.58 \%$, for experimental diets with the lowest and highest ME content (Table 3), respectively, showing a low variation between the evaluated treatments. CF also presented a low variation $12.55 \%$ and $2.79 \%$ ). However, the EE ranged from 3.42 to $7.60 \%$ for diets with the lowest and highest energy value, respectively.

For the most part, EE (Table 3) and ME values (Table 1) reflected variations in the ingredients since the experimental diets were formulated to be isonutritive and vary only in ME levels. Consequently, the variation in $\mathrm{EE}$ content was evident since the different ME levels were attributable to the inclusion of soybean oil in the diets. This variation in inclusion of oil in the experimental diets resulted in GE values of 3600 and $4056 \mathrm{kcal} \mathrm{kg}^{-1}$, for the lowest and highest energy levels used, respectively (Table 3).

The gross energy digestibility coefficient represents the absorbed GE percentage, and the closer to 100 the more efficient the GE absorption diet. Although inclusion of the lipid sources influences the digestibility of certain swine diet compounds (Su et al., 2015), the GEDC of experimental diets did not present significant variations (91\% and $90 \%)$.

The highest GEDC levels observed (Table 3) may be related to the fact that finishing pigs have higher enzyme activity in the brush border membrane. The enterocytes microvilli contain a wide variety of digestive enzymes to catalyze nutrient hydrolysis, such as protein-degrading peptidases, carbohydrate-degrading carboxylases, and small amounts of intestinal lipase responsible for fat depletion (Kerr et al., 2015).

The highest diet digestibility level is also provided by the ease with which lipids can form micelles in the presence of bile salts during digestion. Short chain fatty acids have a higher affinity for micelle formation or can be absorbed directly into the bloodstream. These characteristics make possible the best use of dietary energy (Gu and Li, 2003; Kerr et al., 2015).

The gross energy metabolizable coefficient is represented by the GE percentage used in the form of ME by pigs, because it accounts for the energy retained by metabolism only. The GEMC of the experimental diets were $87 \%$ and $86 \%$, for the diets with the highest and lowest ME levels, respectively, presenting behavior similar to GEMC, since the experimental diets were isonitrogenated, without influence on the deamination of amino acids in the metabolism, which can influence the urine nitrogen concentration and, consequently, the GEMC.

The imbalance of dietary components, particularly amino acids, changes energy: protein ratios since all the nutrients of a diet are directly balanced according to their energy characteristics (Kerr et al., 2015). Thus, experiments that evaluate the NE requirement using isoprotein diets have the energy value of diets influenced by the inclusion of lipids.
The digestible energy values of the experimental diets were 3276 and $3662 \mathrm{kcal} \mathrm{kg}^{-1}$. The ME diet values were 3120 and $3495 \mathrm{kcal} \mathrm{kg}^{-1}$, respectively, for diets with the lowest and highest energy level. The ME values calculated were close to the ME values observed, as shown in Table 1.

The ME:DE ratio shows the degree of efficient use of DE in ME and, according to Noblet and Perez (1993), this ratio for complete diets is usually $96 \%$. The results observed in this experiment are in agreement with these values, since the ME:DE ratio found for diets with the highest and lowest ME levels were $95 \%$ for both. This similarity between the ME:DE ratios is due to the diets being isonitrogenated, as already previously mentioned.

The chemical composition and the energy values of experimental diets (Table 3) are consistent with the values calculated and those presented in the mentioned literature, providing meticulous accuracy in the estimation of NE values of the experimental diets (Table 3) since the equation used to predict $\mathrm{NE}$ values depends on the accuracy and precision of $\mathrm{ME}$ results and from the chemical composition of the experimental diets (EE, S, CP and CF). NE values were estimated at 2345 and $2665 \mathrm{kcal} \mathrm{kg}^{-1}$, respectively, for the diets with the lowest and highest energy levels.

\section{Experiment II - Performance, blood parameters, carcass traits and pork quality}

There was no difference $(p>0.05)$ in final weight (FW) and NE Intake (Table 4) of pigs in the finishing phase. However, there was a reduction ( $p \leq 0.00039)$ in the ADFI as a function of the increase in dietary NE levels.

For several years, the prevailing concept was that swine consumed feed to meet their energy requirements. However, feed intake control based on energy requirement may be a mechanism overlapped by others that are affected by both dietary and nondietary factors (Patience, 2015).

The ADFI reduction observed in the present study may be due to the increase in diet lipid inclusion (Table 1), in addition to NE levels, since the increased absorption of lipids by small intestine promotes CCK (cholecystokinin) hormone secretion and stimulates the synthesis and release of apolipoprotein A-IV (apo A-IV) by enterocytes, normally associated with chylomicrons. Evidence suggests that this peptide is able to regulate feed intake through satiety control and that high levels of dietary energy inhibit intestinal motility and reduce the passage rate (Tso and Liu, 2004).

The energy level of the diet modulates the swine's feed efficiency particularly in two ways: first, with the NE increase the swine's energy requirements are reached with less feed intake and secondly, the 
growth rate is potentiated with high energy levels improving the dietary use of amino acids (Patience, 2015) as shown in Table 4 and Figure $1 \mathrm{~A}$.

Thus, the determination of the swine NE requirements aims to adjust the energy intake so that it is neither deficient nor excessive when providing the maximum $\mathrm{ADG}$, resulting in higher carcass fat deposition. Consequently, the efficiency with which pigs use the available energy to deposit proteins and fats can be evaluated through the ADG. In the present study, a quadratic effect $(\hat{\mathrm{Y}}=$ $\left.-24.0636+0.0203289 X-0.00000407650 X^{2} ; R^{2}=0.96\right)$ was observed in ADG as a function of the NE levels increase in diet (Figure 1B) in which the optimum NE level was estimated at $2493 \mathrm{kcal} \mathrm{kg}^{-1}$.

The ADG response to dietary energy concentration was observed by Quiniou and Noblet (2012), who estimated the best NE level to be $2364 \mathrm{kcal}$ $\mathrm{kg}^{-1}$. Saraiva et al. (2014) also observed an effect of NE levels on swine ADG when assessing the energy ratio with the diet $\mathrm{CP}$ reduction estimating the optimum NE level at $2588 \mathrm{kcal} \mathrm{kg}^{-1}$.

These divergences between the values observed in the present study and those in the literature may be related to the swine's genetic characteristics for different growth rates, energy intake, body temperature maintenance and protein and lipid deposition, which change energy requirements for maintenance (Li et al., 2018).

The benefit of using NE systems was also observed in the improvement in the swine $\mathrm{F}: \mathrm{G}$ ratio (Cámara et al., 2016; Cámara et al., 2014), which was observed in the present study (Table 4) since NE levels produced an effect $(p \leq 0.04)$ on the $\mathrm{F}$ : G ratio (Figure $1 \mathrm{C})$, estimating the best level at $2533 \mathrm{kcal} \mathrm{NE} \mathrm{kg}^{-1}$. On the other hand, Zhang et al. (2011) working with pigs between 30 and $100 \mathrm{~kg}$ estimated $2398 \mathrm{kcal} \mathrm{kg}^{-1}$ as the best dietary NE level for F:G ratio.

Thus, all diet components are directly or indirectly associated with a complex intermediate metabolism pathway (Chwalibog et al., 2005) and the blood plasma metabolic profile is a reflection of this dynamic in response to the nutrient concentration in diet (Zhao et al., 2015). However, when increasing the diets' lipid content no significant effects $(p>$ 0.05) of NE levels were observed on total cholesterol, triglycerides, urea nor on the glucose concentration in the blood plasma (Table 5).

Vegetable fats are compounds rich in polyunsaturated fatty acids. This characteristic is capable of maintaining cholesterol hepatic synthesis at constant levels in the blood in line with increases in the dietary energy of swine (Ho et al., 1989), which may be related to the results obtained for total cholesterol in the present study (Table 5).

The highest lipid concentration in cells depends on the balance between lipogenesis and triglyceride lipolysis. Fat deposition in adipose tissue is controlled by lipoprotein activity which regulates the uptake of fatty acids in the blood (blood triglycerides), and from the lipase enzyme which controls the fatty acid synthesis in adipose tissue $(\mathrm{Gu}$ and $\mathrm{Li}, 2003$; Kerr et al., 2015). In this study, the reduction in ADFI (Table 4) may have provided a standardized lipid intake which does not affect the triglyceride results in the swine's plasma (Table 5).

Table 4 - Performance of finishing pigs fed diets with different levels of net energy.

\begin{tabular}{|c|c|c|c|c|c|c|c|c|}
\hline \multirow{2}{*}{ Item } & \multicolumn{5}{|c|}{ Net Energy (kcal kg-1) } & \multirow{2}{*}{$\mathrm{SEM}^{7}$} & \multicolumn{2}{|c|}{$p$ value } \\
\hline & 2345 & 2425 & 2505 & 2585 & 2665 & & $\operatorname{Lin}^{1}$ & Quad $^{2}$ \\
\hline Initial Weight, kg & 69.69 & 70.49 & 70.16 & 69.78 & 70.38 & 0.187 & 0.6248 & 0.7764 \\
\hline Final Weight, kg & 99.74 & 101.45 & 101.22 & 100.71 & 99.05 & 0.642 & 0.6271 & 0.1805 \\
\hline $\mathrm{ADFl}^{3}, \mathrm{~kg}$ & 3.25 & 3.17 & 3.02 & 2.96 & 2.93 & 0.033 & 0.0004 & 0.4779 \\
\hline NE.Intak, kcal d-1 & 7618 & 7694 & 7569 & 7655 & 7804 & 72,863 & 0.5330 & 0.5718 \\
\hline $\mathrm{NE} . \mathrm{Ef}^{4}, \mathrm{kcal} \mathrm{kg}^{-1} . \mathrm{ADG}$ & 6488 & 6074 & 5995 & 6198 & 6847 & 110,44 & 0.1893 & 0.0027 \\
\hline $\mathrm{ADG}^{5}, \mathrm{~kg}$ & 1.19 & 1.27 & 1.27 & 1.25 & 1.16 & 0.022 & 0.6028 & 0.0352 \\
\hline$F: G^{6}, \mathrm{~kg} \mathrm{~kg}^{-1}$ & 2.77 & 2.50 & 2.39 & 2.40 & 2.57 & 0.044 & 0.0491 & 0.0024 \\
\hline
\end{tabular}

$\mathrm{ADFI}=$ Average daily feed intake; NE.Intake $=$ Net energy intake; NE.Ef $=$ Net energy efficiency; $A D G=$ Average daily gain; F:G = Feed gain ratio; ${ }^{1}$ Net energy linear effect; ${ }^{2}$ Net energy quadratic effect; ${ }^{3 \hat{Y}}=5.734490-0.00106522 X\left(R^{2}=0.93\right) ;{ }^{4} \hat{Y}=172008-133.612 X+0.0268792 X^{2}\left(R^{2}=1.00\right) ;{ }^{5} \hat{Y}=-24.0636+$ $0.0203289 X-0.00000407650 X^{2}\left(R^{2}=0.96\right) ;{ }^{6} \hat{Y}=72.8179-0.0556056 X+0.0000109736 X^{2}\left(R^{2}=1.00\right) ;{ }^{7} S E M=$ Standard Error of the Mean.

Table 5 - Plasma parameters of finishing pigs fed diets with different net energy levels.

\begin{tabular}{|c|c|c|c|c|c|c|c|c|}
\hline \multirow{2}{*}{$\begin{array}{l}\text { Item } \\
\text { Analysis }\left(\mathrm{mg} \mathrm{dL}^{-1}\right)\end{array}$} & \multicolumn{5}{|c|}{ Net energy $\left(\mathrm{kcal} \mathrm{kg}^{-1}\right)$} & \multirow{2}{*}{$\mathrm{SEM}^{3}$} & \multicolumn{2}{|c|}{$p$ value } \\
\hline & 2365 & 2425 & 2505 & 2585 & 2665 & & $\operatorname{Lin}^{1}$ & Quad $^{2}$ \\
\hline Cholesterol & 77.50 & 78.56 & 80.54 & 80.63 & 79.63 & 2.187 & 0.6543 & 0.7189 \\
\hline Triglycerides & 34.25 & 35.13 & 35.00 & 34.50 & 35.50 & 1.285 & 0.8422 & 0.9910 \\
\hline Urea & 24.51 & 24.76 & 25.38 & 23.06 & 21.35 & 0.780 & 0.1479 & 0.2936 \\
\hline Glucose & 79.29 & 79.83 & 79.31 & 79.50 & 80.11 & 0.709 & 0.8004 & 0.8917 \\
\hline
\end{tabular}

${ }^{1}$ Net energy linear effect; ${ }^{2}$ Net energy quadratic effect; ${ }^{3} \mathrm{SEM}=$ Standard error of the mean. 

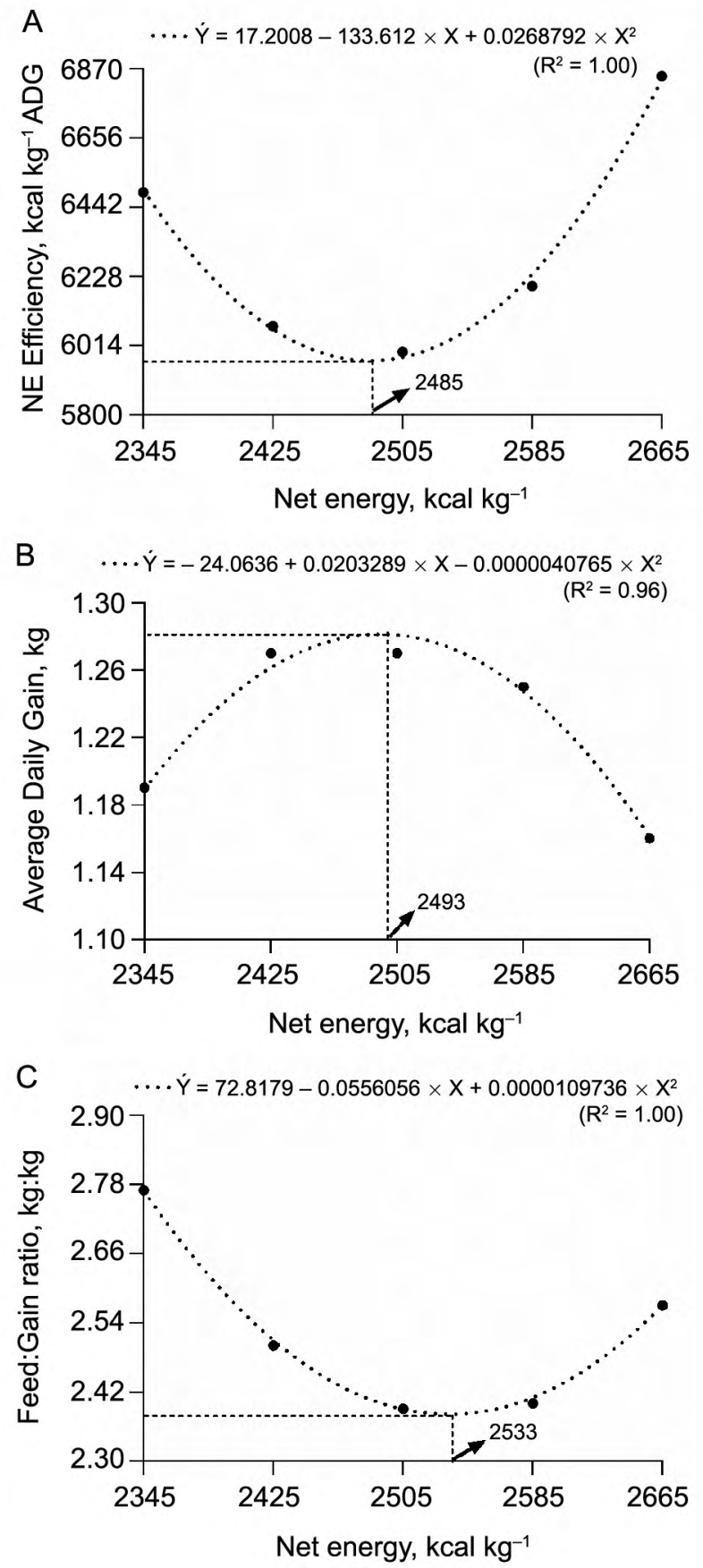

Figure 1 - Graphical representation of net energy efficiency (A), average daily gain (B) and feed gain ratio (C) of finishing pigs fed diets with different net energy levels.

Dietary amino acids are incorporated into the bloodstream to act on metabolic processes related to protein synthesis. Consequently, swine plasma urea levels were not significant $(p>0.05)$ because the experimental diets were isonitrogenated which minimized the nitrogen imbalance effects during protein metabolism (Wu, 2009; Zhao et al., 2019).
Already the blood glucose concentration can be related to the metabolization of dietary carbohydrates, which represents the major source of energy for pigs. The plasma glucose levels were not affected ( $p>0.05)$ by NE levels, due to the experimental diets presenting similar contents of carbohydrates, mainly starch (Tables 1 and 3).

Thus, it can be inferred that finishing pigs maintain their blood metabolite concentration at normal level when dietary energy levels are obtained from the inclusion of soybean oil in diet, associated with the reduction in ADFI.

Currently, the consumer pork market is looking for a lower fat percentage carcass, but one that is able to keep the same yield rates. Carcass yield (CY) is the main economic driver for swine production. However, when finishing pigs have amounts of energy above their metabolic needs, increased fat deposition in the carcass has been observed (Quiniou and Noblet, 2012).

The highest carcass fat deposition may be due to high diet energy: protein, amino acid imbalance, or can be attributed to a specific action of dietary lipids on carcass composition. Even so, increasing diet NE levels did not affect $(p>0.05)$ the DLL muscle, BT, the carcass length (CL), HCW, HCY, CCW, cold carcass yield (CCY), HW and HY as shown in Table 6.

Another important aspect, in addition to a carcass with a lower fat content, is the pork quality. The majority of factors affecting meat quality can be controlled during the production steps. A number, however, are affected by the raising period as well as the time during or after the slaughter process. Furthermore, the diet composition can influence meat quality since the dietary energy: protein ratio determines the protein and lipid deposition rate in the carcass (Wood et al., 2008; Cheng et al., 2017).

The meat products' appearance such as color, softness and succulence are characteristics responsible for inducing the purchase desire, as well as ensuring purchase continuity by consumers. Thus, swine production uses quality indexes to adjust the meat's physical and organoleptic characteristics according to the consumer market (Zhang et al., 2008).

In this study, no effects $(p>0.05)$ of NE levels on qualitative carcass characteristics were observed for $\mathrm{pH} 45, \mathrm{pH} 24, \mathrm{P} 1 \mathrm{P} 2 \mathrm{P} 3$, Minolta $\mathrm{L}^{*}$ and Minolta $\mathrm{b}^{*}$ (Table 7). However, there was a decreasing linear effect ( $p \leq 0.0001)$ for $\mathrm{DL}$, represented by the equation $\hat{\mathrm{Y}}=27.4007-0.00904320 \mathrm{X}\left(\mathrm{R}^{2}=0.93\right)$ and for Minolta $\mathrm{a}^{*}$ value $(p \leq 0.0462)$, as observed in the equation $\hat{\mathrm{Y}}$ $=11.4273-0.00161462 \mathrm{X}\left(\mathrm{R}^{2}=0.68\right)$. The NE levels effects on DL and $\mathrm{a}^{*}$ value may be related to the increased intramuscular fat (IMF) deposition in the carcass (Zhang et al., 2008).

The highest intramuscular fat synthesis is found during the swine finishing phase. Normally, this IMF is influenced by either genetic characteristics (Schwab 
Table 6 - Quantitative characteristics of finishing pigs fed diets with different net energy levels.

\begin{tabular}{|c|c|c|c|c|c|c|c|c|}
\hline \multirow{2}{*}{ Item } & \multicolumn{5}{|c|}{ Net energy $\left(\mathrm{kcal} \mathrm{kg}^{-1}\right)$} & \multirow{2}{*}{$\mathrm{SEM}^{3}$} & \multicolumn{2}{|c|}{$p$ value } \\
\hline & 2345 & 2425 & 2505 & 2585 & 2665 & & $\operatorname{Lin}^{1}$ & Quad $^{2}$ \\
\hline LDD, $\mathrm{mm}$ & 62.87 & 62.10 & 62.98 & 60.22 & 61.61 & 0.928 & 0.4959 & 0.9280 \\
\hline BT, mm & 11.48 & 12.27 & 11.59 & 11.88 & 11.71 & 0.315 & 0.9740 & 0.7195 \\
\hline $\mathrm{CL}, \mathrm{cm}$ & 89.57 & 92.56 & 93.42 & 95.21 & 94.25 & 0.735 & 0.0515 & 0.1542 \\
\hline HCW, kg & 76.17 & 77.40 & 78.45 & 77.28 & 77.34 & 0.561 & 0.5676 & 0.2581 \\
\hline $\mathrm{HCY}, \%$ & 79.96 & 80.38 & 81.04 & 81.49 & 81.50 & 0.334 & 0.1071 & 0.7136 \\
\hline CCW, kg & 73.46 & 75.31 & 76.62 & 76.02 & 74.86 & 0.575 & 0.2984 & 0.0512 \\
\hline CCY, $\%$ & 78.67 & 79.24 & 79.20 & 79.20 & 78.41 & 0.199 & 0.6929 & 0.1350 \\
\hline $\mathrm{HW}, \mathrm{kg}$ & 10.95 & 10.79 & 11.30 & 10.41 & 10.92 & 0.131 & 0.5930 & 0.9414 \\
\hline $\mathrm{HY}, \%$ & 29.42 & 28.43 & 29.50 & 27.95 & 29.21 & 0.246 & 0.5834 & 0.2462 \\
\hline
\end{tabular}

LDD = Longissimus dorsi depth; $\mathrm{BT}=$ backfat thickness; $\mathrm{CL}=$ carcass length; $\mathrm{HCW}=$ hot carcass weight; $\mathrm{HCY}=$ hot carcass yield; CCW = cold carcass weight; CCY = cold carcass yield; $\mathrm{HW}=$ ham weight; $\mathrm{HY}=$ ham yield; ${ }^{1}$ Net energy linear effect; ${ }^{2}$ Net energy quadratic effect; ${ }^{3} \mathrm{SEM}=\mathrm{Standard}$ error of the mean.

Table 7 - Qualitative characteristics Longissimus dorsi muscle of finishing pigs fed diets with different levels of net energy.

\begin{tabular}{|c|c|c|c|c|c|c|c|c|}
\hline & \multicolumn{5}{|c|}{ Net energy $\left(\mathrm{kcal} \mathrm{kg}^{-1}\right)$} & \multirow{2}{*}{$\mathrm{SEM}^{5}$} & \multicolumn{2}{|c|}{$p$ value } \\
\hline & 2345 & 2425 & 2505 & 2585 & 2665 & & $\operatorname{Lin}^{1}$ & Quad $^{2}$ \\
\hline $\mathrm{pH}-45 \mathrm{~min}$ & 5.88 & 5.92 & 6.02 & 5.95 & 6.02 & 0.064 & 0.2831 & 0.8404 \\
\hline $\mathrm{pH}-24 \mathrm{~h}$ & 5.82 & 5.84 & 5.89 & 5.91 & 5.89 & 0.054 & 0.5920 & 0.8234 \\
\hline P1P2P3, cm & 2.52 & 2.38 & 2.20 & 2.24 & 2.23 & 0.058 & 0.0742 & 0.2962 \\
\hline $\mathrm{DL}^{3}(\%)$ & 5.98 & 5.49 & 5.27 & 3.79 & 3.21 & 0.197 & 0.0001 & 0.1581 \\
\hline Minolta $\left(\mathrm{L}^{*}\right)$ & 54.55 & 54.51 & 54.57 & 54.51 & 55.20 & 0.216 & 0.3945 & 0.4563 \\
\hline Minolta $\left(a^{*}\right)^{4}$ & 7.70 & 7.34 & 7.42 & 7.43 & 7.01 & 0.106 & 0.0462 & 0.8122 \\
\hline Minolta $\left(b^{*}\right)$ & 3.83 & 3.58 & 3.57 & 3.89 & 3.72 & 0.093 & 0.8829 & 0.5308 \\
\hline
\end{tabular}

pH 45 - pH 45 min after slaughter; pH $24-\mathrm{pH} 24 \mathrm{~h}$ after slaughter; P1P2P3 = carcass measurement points to evaluate fat thickness; DL = drip loss; ${ }^{1} \mathrm{Net}$ energy linear effect; ${ }^{2}$ Net energy quadratic effect; ${ }^{3} \hat{Y}=27.4007-0.00904320 \mathrm{X}\left(R^{2}=0.93\right) ;{ }^{4} \hat{Y}=11.4273-0.00161462 X\left(R^{2}=0.68\right) ;{ }^{5}$ EM $=$ Standard Error of the Mean.

et al., 2006) or the nutritional aspects. Consequently, the energy level, the energy:lysine ratio and diet low energy density can increase the IMF deposition in swine carcass (Zhang et al., 2008).

This fat is intermixed with muscle fibers and may have increased the membrane stability during the conversion of the muscle into meat. The muscle structure is composed of approximately $75 \%$ water among other components such as proteins $( \pm 20 \%)$, lipids $( \pm 5 \%)$, carbohydrates $( \pm 1 \%)$, vitamins and minerals (Pearce et al., 2011).

After slaughter, in the rigor mortis process, sarcomere shortening promotes the osmotic imbalance of the muscle cells and, as a consequence, the actin-myosin complexes reduce the muscle intra-myofibrillary spaces, providing water molecule mobilization from the intra-myofibrillar spaces to the extra-myofibrillar spaces. In the post mortem period, the meat turns soft again due to the muscle fibers rupturing and the electrolyte balance returns of cells; however, the extra-myofibrillar spaces end up forming water drip channels that provide meat DL (Table 7) (Pearce et al., 2011).

In cases of high temperature and rapid $\mathrm{pH}$ drop, myosin heads are rapidly denatured and actinmyosin complexes are formed, providing a higher muscle cell structural disintegration, as well as increasing the water content in extra-myofibrillar spaces, reducing the meat water retention capacity (Pearce et al., 2011). In the present study, the $\mathrm{pH}$ values (Table 7) and temperature did not change muscle tissue metabolism during the post mortem process, providing evidence of the DL reduction in swine loins (Figure 2A), being attributable to higher IMF deposition as a result of increased NE levels in diet (Zhang et al., 2008).

According to Zhang et al. (2008), swine fed diets with low energy density have a higher IMF deposition, lower water retention capacity and higher $a^{*}$ values for the loins. The $a^{*}$ value represents the green color $\left(-a^{*}\right)$ until the red color appears $\left(+a^{*}\right)$ and the greater the meat $+a^{*}$ the higher its intensity for the red color. However, in the present study (Table 7), the reduction in the Minolta $a^{*}$ value may be related to the increased IMF deposition. This in turn is intermixed with the muscle fibers and reduces the intensity of the meat's reddish tone (Figure 2B).

\section{Authors' Contributions}

Conceptualization: Moreira, C.A.; Pozza, P.C. Data acquisition: Moreira, C.A.; Bonagúrio, L.P.; Sitanaka, N.Y.; Esteves, L.A.C. Design of methodology: Pozza, P.C. Writing and editing: Moreira, C.A.; Pozza, P.C. 

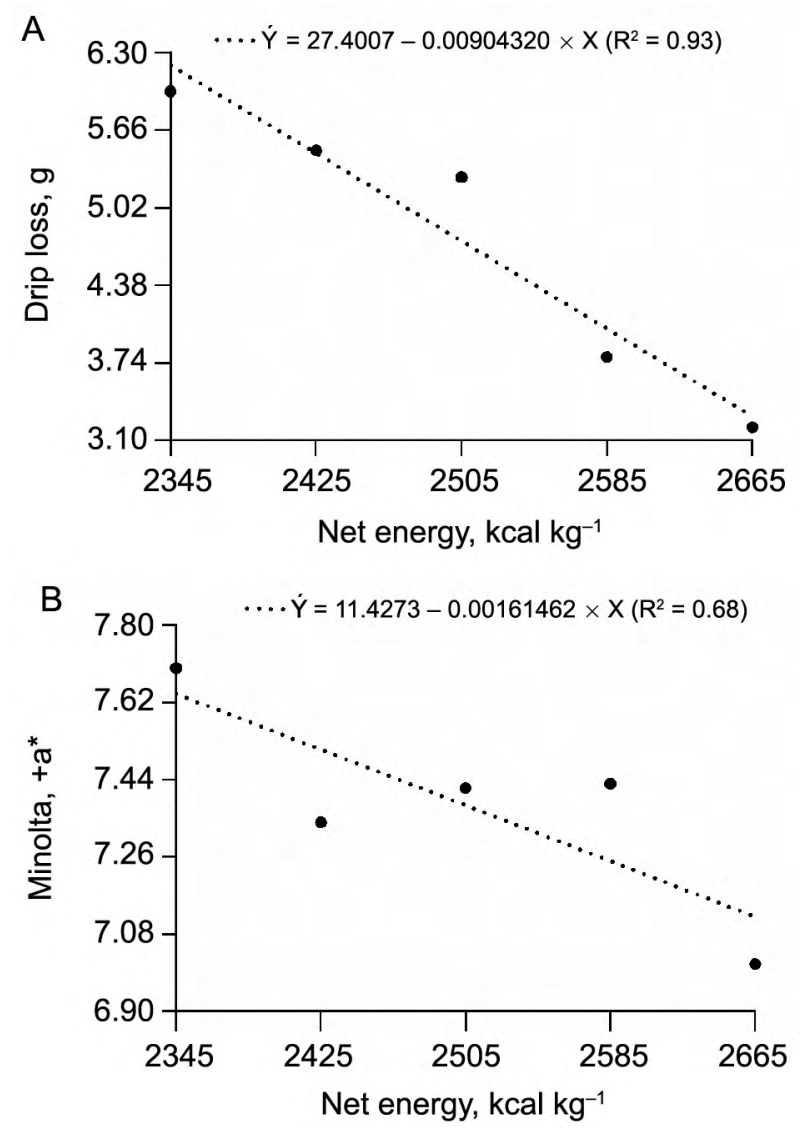

Figure 2 - Graphic representation of drip loss (A) and Minolta a* (B) of Longissimus dorsi muscle of finishing pigs fed diets with different levels of net energy.

\section{References}

Association of Official Analytical Chemists - International [AOAC]. 2006. Official Methods of Analysis. 18ed. AOAC, Arlington, VA, USA.

Boccard, R.; Buchter, L.; Casteels, E.; Cosentino, E.; Dransfild, E.; Hood, H.E.; Joseph, R.L.; MacDougall, B.D.; Rhodes, N.D.; Schon, I.; Tinbergen, B.J.; Touraille, C. 1981. Procedures for measuring meat quality characteristics in beef production experiments. Report of a working group in the Commission of the European Communities'(CEC) beef production research programme. Livestock Production Science 8: 385-397.

Bridi, A.M.; Silva, C.A. 2009. Pork Meat Evaluation = Avaliação da Carne Suína. Midiograft, Londrina, PR, Brazil (in Portuguese).

Cai, Y.; Zimmerman, D.R.; Ewan, R.C. 1994. Diurnal variation in concentrations of plasma urea nitrogen and amino acids in pigs given free access to feed or fed twice daily. The Journal of Nutrition 124: 1088-1093.

Cámara, L.; Berrocoso, D.J.; Coma, J.; López-Bote, C.J.; Mateos, G.G. 2016. Growth performance and carcass quality of crossbred pigs from two Pietrain sire lines fed isoproteic diets varying in energy concentration. Meat Science 114: 69-74.
Cámara, L.; Berrocoso, D.J.; Sánchez, J.L.; López-Bote, C.J.; Mateos, G.G. 2014. Influence of net energy content of the diets on productive performance and carcass merit of gilts, boars and immunocastrated males slaughtered at $120 \mathrm{~kg}$ BW. Meat Science 98: 773-780.

Cheng, C.; Liu, Z.; Zhou, Y.; Wei, H.; Zhang, X.; Xia, M.; Deng, Z.; Zou, Y.; Peng, J. 2017. Effect of oregano essential oil supplementation to a reduced-protein, amino acidsupplemented diet on meat quality, fatty acid composition, and oxidative stability of Longissimus thoracis muscle in growingfinishing pigs. Meat Science 133: 103-109.

Chwalibog, A.; Jokobsen, K.; Tauson, H.A.; Thorbek, G. 2005. Energy metabolism and nutrient oxidation in young pigs and rats during feeding, starvation and re-feeding. Comparative Biochemistry and Physiology Part A: Molecular \& Integrative Physiology 140: 299-307.

Gu, X.; Li, D. 2003. Fat nutrition and metabolism in piglets: a review. Animal Feed Science and Technology 4: 151-170.

Ho, H.-T.; Kim, D.N.; Lee, K.T. 1989. Intestinal apolipoprotein B-48 synthesis and lymphatic cholesterol transport are lower in swine fed high fat, high cholesterol diet with soy protein than with casein. Atherosclerosis 77: 15-23.

Kerr, B.J.; Kellner, T.A.; Shurson, G.C. 2015. Characteristics of lipids and their feeding value in swine diets. Journal of Animal Science and Biotechnology 6: 30.

Kil, D.Y.; Kim, B.G.; Stein, H-H. 2013. Feed energy evaluation for growing pigs. Asian-Australasian Journal of Animal Sciences 26: $1205-1217$.

Li, Z.; Liu, H.; Li, Y.; Lv, Z.; Liu, L.; Lai, C.; Wang, J.; Wang, F.; Li, D.; Zhang, S. 2018. Methodologies on estimating the energy requirements for maintenance and determining the net energy contents of feed ingredients in swine: a review of recent work. Journal of Animal Science and Biotechnology 9: 39.

Moehn, S.; Levesque, C.L.; Ball, R.O. 2013. Protein intake but not feed intake affects dietary energy for finishing pigs. Journal of Animal Physiology and Animal Nutrition 97: 197-204.

Moreno, A.M.; Sobestiansky, J.; Lopez, A.C.; Sobestiansky, A.A.B. 1997. Collection and processing of blood samples in swine for diagnostic purposes $=$ Colheita e processamento de amostras de sangue em suinos para fins de diagnostico. Embrapa Suínos e Aves, Concordia, SC, Brazil. (EMBRAPA-CNPSA. Documentos, 41) (in Portuguese).

Noblet, J.; Perez, J.M. 1993. Prediction of digestibility of nutrients and energy values of pig diets from chemical analysis. Journal of Animal Science 71: 3389-3398.

Noblet, J.; Fortune, H.; Shi, X.S.; Dubois, S. 1994. Prediction of net energy value of feeds for growing pigs. Journal of Animal Science 72: 344-354.

Noblet, J. 2007. Net energy evaluation of feeds and determination of net energy requirements for pigs. Revista Brasileira de Zootecnia 36: 277-284.

Patience, J.F.; Rossoni-Serão, A.C.; Gutiérrez, N.A. 2015. A review of feed efficiency in swine: biology and application. Journal of Animal Science and Biotechnology 6: 33.

Pearce, K.L.; Rosenvold, K.; Andersen, H.J.; Hopkins, D.L. 2011. Water distribution and mobility in meat during the conversion of muscle to meat and ageing and the impacts on fresh meat quality attributes: a review. Meat Science 89: 111-124. 
Pekas, J.C. 1968. Versatible swine laboratory apparatus for physiologic and metabolic studies. Journal of Animal Science 27: $1303-1306$.

Quiniou, N.; Noblet, J. 2012. Effect of the dietary net energy concentration on feed intake and performance of growingfinishing pigs housed individually. Journal of Animal Science 90: 4362-4372.

Rostagno, H.S.; Albino, L.F.T.; Donzele, J.L.; Gomes, P.C.; Oliveira, R.D.; Lopes, D.C.; Barreto, S.D. 2005. Brazilian Tables for Poultry and Pigs: Food Composition and Nutritional Requirements = Tabelas Brasileiras para Aves e Suínos: Composição de Alimentos e Exigências Nutricionais. Editora UFV, Viçosa, MG, Brazil (in Portuguese).

Rostagno, H.S.; Albino, L.F.T.; Hannas, M.I.; Donzele, J.L.; Sakomura, N.K.; Perazzo, F.G.; Brito, C.O. 2017. Brazilian Tables for Poultry and Pigs: Food Composition and Nutritional Requirements $=$ Tabelas Brasileiras para Aves e Suínos: Composição de Alimentos e Exigências Nutricionais. Editora UFV, Viçosa, MG, Brazil (in Portuguese).

Saraiva, A.; Donzele, J.L.; Oliveira, R.F.M.D.; Silva, F.C.D.O.; Abreu, M.L.T.; Santos, F.D.A.; Haese, D. 2014. Net energy for 60 to $120 \mathrm{~kg}$ pigs fed low-crude protein diets. Ciência Rural 44: 1632-1638.

Schinckel, A.P.; Einstein, M.E.; Jungst, S.; Matthews, J.O.; Booher, C.; Dreadin, T.; Fralick, C.; Wilson, E.; Boyd, R.D. 2012. Daily feed intake, energy intake, growth rate and measures of dietary energy efficiency of pigs from four sire lines fed diets with high or low metabolizable and net energy concentrations. AsianAustralasian Journal of Animal Sciences 25: 410.

Schwab, C.R.; Baas, T.J.; Stalder, K.J.; Mabry, J.W. 2006. Effect of long-term selection for increased leanness on meat and eating quality traits in Duroc swine. Journal of Animal Science 84: 1577-1583.

Smith, J.W.; O`Quinn, P.R.; Goodband, R.D.; Tokach, M.D.; Nelssen, J.L. 1999. Effects of low-protein, amino acid-fortified diets formulated on a net energy basis on growth performance and carcass characteristics of finishing pigs. Journal of Applied Animal Research 15: 1-16.

Su, Y.; She, Y.; Huang, Q.; Shi, C.; Li, Z., Huang, C.; Piao, X.; Li, D. 2015. The effect of inclusion level of soybean oil and palm oil on their digestible and metabolizable energy content determined with the difference and regression method when fed to growing pigs. Asian-Australasian Journal of Animal Sciences 28: 1751 .
Tso, P.; Liu, M. 2004. Apolipoprotein A-IV, food intake, and obesity. Physiology \& Behavior 83: 631-643.

Velayudhan, D.E.; Nyachoti, C.M. 2016. Net energy system of feed formulation with or without enzyme supplementation in growing-finishing pigs fed barley-based diets with alternative feed ingredients. Canadian Journal of Animal Science 96: 180186.

Weber, T.E.; Trabue, S.L.; Ziemer, C.J.; Kerr, B.J. 2010. Evaluation of elevated dietary corn fiber from corn germ meal in growing female pigs. Journal Animal Science 88: 192-201.

Wood, J.D.; Enser, M.; Fisher, A.V.; Nute, G.R.; Sheard, P.R.; Richardson, R.I.; Hughes, S.I.; Whittington, F.M. 2008. Fat deposition, fatty acid composition and meat quality: a review. Meat Science 78: 343-358.

Wu, G. 2009. Amino acids: metabolism, functions, and nutrition. Amino Acids 37: 1-17.

Zhang, J.; Yin, J.; Zhou, X.; Li, F.; Ni, J.; Dong, B. 2008. Effects of lower dietary lysine and energy content on carcass characteristics and meat quality in growing-finishing pigs. Asian-Australasian Journal of Animal Sciences 21: 17851793.

Zhang, G.J.; Yi, X.W.; Chu, L.C.; Ning, L.U.; Htoo, J.; Qiao, S.Y. 2011. Effects of dietary net energy density and standardized ileal digestible lysine: net energy ratio on the performance and carcass characteristic of growing-finishing pigs fed low crude protein supplemented with crystalline amino acids diets. Agricultural Sciences in China 10: 602-610.

Zhao, P.Y.; Li, H.L.; Hossain, M.M.; Kim, I.H. 2015. Effect of emulsifier (lysophospholipids) on growth performance, nutrient digestibility and blood profile in weanling pigs. Animal Feed Science and Technology 207: 190-195.

Zhao, Y.; Tian, G.; Chen, D.; Zheng, P.; Yu, J.; He, J.; Mao, X.; $\mathrm{Yu}$, B. 2019. Effects of varying levels of dietary protein and net energy on growth performance, nitrogen balance and faecal characteristics of growing-finishing pigs. Revista Brasileira de Zootecnia, 48: e20180021. 